\section{SCIENCE IN AMERICA}

THE following appropriations by the U.S. Congress were made at the session of $1869-70$ for the ensuing year, July 1,1870 , to June $30,187 \mathrm{I}$, in aid of Science, Literature, \&c.

It should be observed that the undermentioned appropriations are those of the Generil Government, and not those of the separate States, which, in the aggregate, would far exceed the amount here presented.

\section{Museums.}

National Museum in charge of

Smithsonian Institution. .

Army Medical Museum. . . .

Agricultural Departmt. Museum .

\section{斗}

Botanic Gardens and Greenhouses.

Of the U.S. Capitol . . . . . 35,996

" " President's House. . . 2,500

" " Agricultural Department 38,200

\section{Agriculture.}

Department of Agriculture, Mis-

cellaneous Expenses. . .

[To this is to be added, items already given,--

Botanic Garden and Living Plants....

Museum. . . . . .

Library - $\cdot$ agregate of or an ag

38,200

8,000

$3,800-50,000$ $\$ 188,070$.

Astronomy and Meteorology.

Observations of Eclipse, Dec. 1870 , under Coast Survey . .

U.S. Nautical Almanac. . .

National Observatory . .

New Telescope for National Observatory . . . . . .

Telegraphic Notices of Storms

29,000

20,000

I 9,800

50,000

50,000

U.S. Coast Survey Surveys, \&c.

Survey of Lakes . . . . . Nicaragua and Tehauntepec Ship Canals. . .

Military Surveys west of Mississippi . . . . . . .

Prof. Powell's Survey of Colorado of West . . . . . . .

Polar Explorations . . .

Dr. Hayden's Geological Survey

Statistics of Mines and Mining.

703,000

I 50,000

30,000

IOO,000

$12,000^{\circ}$

50,000

25,000

10,000

Light-house Establishments. . . . Libraries.

Library of Congress . . . . . $"$ of Medical Department, U.S.A. . . . " of Agriculiural Department . . . .

\section{Education.}

U.S. Department of Eduction .

Wilberforce and Lincoln Univer-

sities . . . . . . .

Benerolent Objects.

Life boat Service nn the Coast .

Government Hospilal for Insane

Columbia Institution for Deaf and Dumb ...... .

Columbia Hospital for Women .

168,800

National Association for Destitute Coloured Women, D.C. .

National Soldiers' and Sailors'

Home, D.C. . . . . . . .

Care of 60 transient Paupers. .

$\$$
$10, \infty 00$

$\$$

15,000

12,000

Total

234,635

$\$ 3,316,928$

THE INFLUENCE OF INTENSE COLD ON STEEL AND IRON

THERE has recently been a most interesting discussion at the Literary and Philosophical Society, Manchester, on the above subject, the result of which seems to be that we must at once give up the idea that such accidents as the one, for instance, near Hatfield, are due to anything beyond the control of the Railway Companies concerned.

The paper which gave rise to the discussion was by Mr. Brockbank, who detailed many experiments, and ended by stating his opinion that iron does become much weaker, both in its cast and wrought state, under the influence of low temperature ; but Mr. Brockbank's paper was immediately followed by others by Sir W. Fairbairn, Dr. Joule, and Mr. Spence, which at once put an entirely new complexion on the matter.

As Dr. Joule's results are the most to the point we may take them first. He says :-

"As is usual in a severe frost, we have recently heard of many severe accidents consequent upon the fracture of the tires of the wheels of railway carriages. The common-sense explanation of these accidents is, that the ground being harder than usual, the metal with which it is brought into contact is more severely tried than in ordinary circumstances. In order apparently to excuse certain Railway Companies, a pretence has been set up that iron and steel become brittle at a low temperature. This pretence, although put forth in defiance, not only of all we know of the properties of materials, but also of the experience of everyday life, has yet obtained the credence of so many people that I thought it would be useful to make the following simple experiments :-

"Ist. A freezing mixture of salt and snow was placed on a table. Wires of steel and of iron were stretched so that a part of them was in contact with the freezing mixture, and another part out of it. In every case I tried the wire broke outside of the mixture, showing that it was weaker at $50^{\circ} \mathrm{F}$. than at about $12^{\circ} \mathrm{F}$.

" 2 nd. I took twelve darning needles of good quality, 3in. long, $\frac{1}{24}$ in. thick. The ends of these were placed against steel props, $2 \frac{1}{8}$ in. asunder. In making an experiment, a wire was fastened to the middle of a needle, the other end being attached to a spring weighing-machine.

36,220

3,000

3,800

14,500

$37, \mathrm{co0}$

$1,080,000$

I,43I, 207 This was then pulled until the needle gave way. Six of the needles, taken at random, were tried at a temperature of $55^{\circ} \mathrm{F}$, and the remaining six in a freezing mixture which brought doun their temperature to $12^{\circ} \mathrm{F}$. The results were as follow :-

Warm Needies. $64 \mathrm{oz}$. broke $65 "$,

$55 "$,

$62 ", "$

44 " " "

Average $58 \frac{1}{3}$

Cold Needles.

55 oz. broke

$64, \quad "$

72 " "

68 " broke

$40 "$,

51,500 48.883

149980
"I did not notice any perceptible difference in the perfection of elasticity in the tuo sets of needles. The result, as far as it gocs, is in avour of the cold metal.

" 3 rd. The above are doubtless decisive of the question at issue. But as it might be alleged that the violence to 